\title{
Elementary Study on the Relationship between Employees' Career Competencies and Turnover Intention
}

\author{
Xixi Wu \\ Business School, East China University of Science and Technology, \\ Shanghai 200237, China \\ wuxixiHRM@163.com
}

\begin{abstract}
Keywords: Career Competencies; Turnover Intention; Human Capital
Abstract. Employee turnover management is an important aspect of organizing human resources management, and turnover intention is the most direct antecedents of employee turnover behavior. Based on previous literature, this paper put forward that career competencies will also influence workers' turnover intention beside compensation, promotion and career satisfaction, etc. The effect of career competencies on turnover intention were discussed from three dimensions, including know-why competencies, know-how competencies, know-whom competencies. The results showed that all the three types of career competencies were negatively correlated with turnover intention. Finally, the paper figured out the disadvantages of this paper and put forward the future research prospects.
\end{abstract}

\section{Introduction}

With the advent of the knowledge economy, the organization exist in an external environment within increased uncertainty. Flat organizational structure also greatly reduces the opportunities for the employees to be vertical promoted to realize career development. Employee mobility increases since these changes have led to employees can not work in a long-term stability environment. What's more, studies show that individuals are more desirable to control their own career and more willing to obtain the environment of life-long learning. All of these changes would bring certain challenges to the enterprise recruitment, management and retention of talent employees.

The main purpose of this paper is to investigate how employees' career competencies affects their turnover intention. Existing research points out a series of antecedents for turnover intention, including individual factors, organizational factors and work-related aspects. Among them, the individual factors includes work-family facilitation and years of working; the organization and work-related factors include the organization administration (e.g., organizational fairness, organizational support) and individual and organization fit (e.g., job satisfaction , organizational commitment). Few scholars have paid attention to the influence of career competencies, a part of human capital, on turnover intention. Traditionally, research on career competencies focused on career competencies concept ${ }^{[1,2]}$, the ways to improve the career competencies ${ }^{[3]}$, the relationship between career competencies and career success ${ }^{[4]}$.Prior research neglect the impact of career competencies on employees' behavior. Therefore, we believe that it will be an efficient way to reduce employee turnover rate by cultivating and developing career competencies especially in the new knowledge-based economy since compensation and promotion can no longer encourage the coworkers effectively.

As a consequence, this article will explore the relationship between employees' career competencies and their turnover intention. The paper is organized as follows. First ,we will have a brief introduction of career competencies and turnover intention, then we discuss the relationship by introducing self-regulation theory and finally we put forward the lack of research and prospect in the end. 


\section{Concept of career competencies and turnover intention}

\section{Career competencies}

The study of career competencies originated in the 1980s, but the study of it was just paid attention by academia community until Arthur proposed 'smart career' based on the 'smart business' raised by Quinn. Career competencies is part of human capital development, individuals' self-management capacity of the work and learning experience to realize the career goals and can be improved through education and training ${ }^{[5],}$ specifically including the know-why competencies, know-how competencies and know-whom career competencies. Among them, the know-why competencies refers to one kind of career motivation, values and identity-related capabilities, including career insight, proactive personality and openness to experience; know-how competencies reflect careerrelated knowledge and skills, including career/work-related skills and job identification; knowwhom competencies refers to build an individual's career-related social network, including the experience in a mentoring relationship, internal and external network ${ }^{[6]}$. Additionally, Some scholars called career competencies as career investments and give the definition that it refers to the time, energy, skills and relationships that the individuals spend on the work and organization.

\section{Turnover intention}

Researches have studies the turnover intention for quite a long time, scholars generally believe that turnover behavior can be predicted by staff turnover intention. Porter and Steers consider the turnover intention as an withdrawal action after unsatisfactory experience ${ }^{[7]}$. Mobley et al. believes that turnover intention is a comprehensive performance of job dissatisfaction, turnover thought, tends to look for other jobs and possibilities to find other jobs ${ }^{[8]}$. Some scholars also put forward the definition of turnover intention by considering the reason of the appearance of turnover intention and hold the view that turnover intention is the outcome of experiencing dissatisfaction. Huang defined it as labor transfer in different regions and industries, which provides a new way to view employee turnover intention.

\section{Preliminary study on the relationship between career competencies and turnover intention}

\section{Theoretical basis - self-regulation theory}

Self-regulation theory refers to individuals' internal process or exchange process to realize the objectives according to the change of time and environment ${ }^{[9]}$. According to social cognition perspective, self-regulation process and its accompanying faith cycle can be divided into three stages: prediction, operation or volitional control and self-reflection. Forecast refers to the process and identify actions to prepare the stage act before the operation; operation or volitional control refers the process that occurred during the operation and behavior and also influence the attention and behavior; self-examination refers to the process that occurred after the operation and behavior and also influence the behavior of individual experience reactions, which in turn impact on subsequent behavior prediction. This completes a cycle of self-regulation ${ }^{[10]}$.

\section{The relationship between career competencies and turnover intention}

Based on the self-regulation theory, individuals with high career competencies possess higher career insight, and career insights refers to the degree that the individuals have realistic career expectations, understand their strength and weakness and have a very definite career objectives, which can help them to better complete the process of self-observation, have realistic and in-depth understanding of themselves and set reasonable and realistic goals ${ }^{[11]}$. Furthermore, career-related skills competencies can help individuals to better achieve the self-target in the organization which can help to gain a lot of opportunities to be promoted and to become the experts in the organization and thus get more respect, honor, reputation and self satisfaction. Individuals with strong competencies to expand social networks can help individuals communicate smoothly in the emotional aspects, so that the perceived degree of person-organization fit increases, then we can expect turnover individuals will be weakened. 


\section{Know-why competencies and turnover intention}

More specifically, the know-why competencies can make individuals to have a more clear selfpositioning, and to find a more comfortable working environment and jobs for themselves, that is to say, the individuals with high know-why competencies could find a more satisfied job in their career, thereby reducing the probability of generating turnover intention. At the same time, knowwhy competencies can increase employees' the sense of mission and job commitment, which can stimulate the internal motivation of employees and work harder ${ }^{[12,13]}$. Employee with high knowwhy competencies will actively seek regular training and development opportunities, so that employees can acquire transferable skills ${ }^{[14]}$, which would make employees more involved in work. Additionally, employees who are satisfied with their careers psychologically identify with their career, and consequently, with their current job.

A study also show that the proactive personality can increase the perceive of the career satisfaction. it is assumed that 'knowing-why' competencies is an important predictor of turnover intention. Highly proactive individuals can identify opportunities more easily and seize the opportunity when it arises, and persevere in the face of difficult position. When people perceived that the job can meet their needs to acquire the competencies, they will work harder. Together, it's expected that higher know-why competencies leads to lower turnover intention.

Know-how competencies and turnover intention

Staff with high know-how competencies has a broad, flexible and transferable knowledge and skills which can increase employees' employability and reduce employee occupational insecurity ${ }^{[15]}$, thus reduce the employees' turnover intention. When an organization provide staff with adequate development opportunities, the staff will be willing to stay in the organization and development themselves. In addition, employees with employability can get more promotion opportunities and a higher pay level, which will increase their career satisfaction.

Know-how competencies can enhance confident and career identity. When they meet difficulties in the work, they are willing to conquer them by their effort rather than feel sick about the job and finally give up the job. In conclusion, the know-how competencies can reduce individuals' turnover by enhancing their employability and their intention to work harder.

Know-whom competencies and turnover intention

Individuals experience career insecurity when they feel powerless to maintain continuous employment (i.e., employability) in their careers. Know-whom competencies refers to the establishment of career-related social networks. Extensive social networks can bring to the staff expertise and learning resources, so that employees will be exposed to more opportunities to gain competitive advantage, which means the individuals will have more resources to develop their career. Study show that individuals in the knowledge economics age are willing to control their own career development, which in turn increase people's happiness in the organization.

The establishment of the relationship with the colleagues and organizations will improve the individuals' degree of embeddedness, and the connections with the colleagues and organizations will prevent the co-workers leave the firm since they will sacrifice a lot if they leave, such as networks with colleagues and attractive project. In addition, when employees talks the career development with the people who plays an important role in the organization, an positive and energetic work atmosphere appears. so that the staff is willing to contribute their efforts to facilitate the development of organization ${ }^{[16]}$. It is assumed that the improvement of know-whom competencies can prevent employees from leaving the organization.

\section{Summary and prospect}

On the basis of previous studies, the present study was to evaluate the influence of career competencies on turnover intention and draw a conclusion that the relationship between career competencies is negative. The paper provide a new perspective to reduce the staff turnover intention and ensure the stability of the organization's internal staff by managing and improving their career competencies. Meanwhile, the finding also have some practical significance that the companies can retain key employees by improving three classes of career competencies. But the paper also has 
shortcomings, only theoretically discusses the relationship between career competencies and turnover intention, based on this, we propose future research directions as follows. Firstly, A lot of empirical studies can be carried out to examine the relationship, we can not only verify the relationship with samples from all over the world, such as developed countries, emerging countries and newly industrialized countries, to compare if there is any differences among them, but also can test the relationship using special samples in specific contexts, take millennial employees in China as an example, the exploration of the relationship between career competencies and turnover intention will be of immense importance to the exploitation and training of the millennial generation, since the millennial generation is commonly considered to be full of innovativeness and the new power of firm, but too hard to manage because of their varied employment concept and stronger self-consciousness.

Secondly, the future research could explore the mechanism of career competencies on turnover intention. As discussed above, the enhancement of the career competencies will improve employees' level of embeddedness. Perhaps it's a way to explore the mechanism on the basis of jobembeddedness theory. Thirdly, if possible we can also investigate the impact of career competencies on other outcome variables, such as job satisfaction, job performance and so on, all of these will inspire the organizations to develop themselves by cultivating the competencies of the employees to achieve a win-win situation. Finally, the company shall perfect the management system and the system of planning of development of the careers of staff from the career competencies perspective.

\section{References}

[1] Arthur $\mathrm{M}$, Inkson $\mathrm{K}$, Pringle J. The new careers: Individual action and economic change[M].Sage, 1999.

[2] Inkson K, Arthur M B. How to be a successful career capitalist[J]. Organizational dynamics, 2001, 30(1): 48-61.

[3] Sturges J, Simpson R, Altman Y. Capitalizing on learning: an exploration of the MBA as a vehicle for developing career competencies[J]. International Journal of Training and Development, 2003, 7(1): 53-66.

[4] Eby L T, Butts M, Lockwood A. Predictors of success in the era of the boundaryless career[J]. Journal of Organizational Behavior, 2003, 24(6): 689-708.

[5] Lertwannawit A, Serirat S, Pholpantin S. Career competencies and career success of Thai employees in tourism and hospitality sector[J]. International Business \& Economics Research Journal (IBER), 2009, 8(11).

[6] Eby L T, Butts M, Lockwood A. Predictors of success in the era of the boundaryless career[J]. Journal of Organizational Behavior, 2003, 24(6): 689-708.

[7] Porter, L. W., Steer, R. M.. Organizational, Work, and Personal Factors in Employee Turnover and Absenteeism. Psychological Bulletin, 1973, 80(2): 151-176.

[8] Mobley, W. H., Horner, S. O., Hollingworth, A. T.. An Evaluation of Precursors of Hospital Employee Turnover. Journal of Applied Psychology, 1978, 63(4): 408-414.

[9] Behncke L. Self-regulation: A brief review[J]. Athletic Insight, 2002, 14(1): 313-25.

[10] Self-regulated learning: From teaching to self-reflective practice[M]. Guilford Press, 1998.

[11] DeFillippi R J, Arthur M B. Boundaryless contexts and careers: A competency-based perspective[J]. The boundaryless career, 1996: 116-131.

[12] DeFillippi R J, Arthur M B. The boundaryless career: A competency-based perspective[J]. Journal of organizational behavior, 1994, 15(4): 307-324. 
[13] Brown S P, Leigh T W. A new look at psychological climate and its relationship to job involvement, effort, and performance[J]. Journal of applied psychology, 1996, 81(4): 358-368.

[14] Banai M, Harry W. Boundaryless global careers: The international itinerants[J]. International Studies of Management \& Organization, 2004, 34(3): 96-120.

[15] Colakoglu S N. The impact of career boundarylessness on subjective career success: The role of career competencies, career autonomy, and career insecurity[J]. Journal of Vocational Behavior, 2011, 79(1): 47-59.

[16] Akkermans J, Schaufeli W B, Brenninkmeijer V, et al. The role of career competencies in the Job Demands-Resources model. Journal of Vocational Behavior, 2013, 83(3): 356-366. 